reflex response that healthcare workers are neglectful of hand hygiene, which, far from helping, only demoralizes them further.

\section{REFERENCES}

1. Simmons B, Bryant J, Nieman K, Spencer L, Arheart K. The role of handwashing in prevention of endemic intensive care unit infections. Infect Control Hosp Epidemiol 1990;11:589-594.

2. Quraishi ZA, McGuckin M, Blais FX. Duration of handwashing in intensive care units: a descriptive study. Am J Infect Control 1984;11:83-87.

3. Graham M. Frequency and duration of handwashing in an intensive care unit. Am J Infect Control 1990;18:77-81.

4. Albert RK, Condie F. Hand-washing patterns in medical intensive-care units. $N$ Engl J Med 1981;304:1465-1466.

5. Doebbeling BN, Stanley GL, Sheetz CT, et al. Comparative efficacy of alternative hand-washing agents in reducing nosocomial infections in intensive care units. N Engl J Med 1992;327:88-93.

6. Dubbert PA, Dolce J, Richter W, Miller M, Chapman SW. Increasing ICU staff handwashing: effects of education and group feedback. Infect Control Hosp Epidemiol 1990;11:191-193.

7. Larson EL, Eke PI, Wilder MP, Laughon BE. Quantity of soap as a variable in handwashing. Infect Control 1987;9:371-375.
8. Widmer AF. Infection control and prevention strategies in the ICU. Intensive Care Med 1994;20(suppl 4):7S-11S.

9. Garner JS, Favero MS. CDC guidelines for handwashing and hospital environmental control. Infect Control 1986;7:231-235.

10. Ehrenkranz NJ. Bland soap handwash or hand antisepsis? The pressing need for clarity. Infect Control Hosp Epidemiol 1992;13:299-301.

11. Perceval A. Wash hands, disinfect hands, or don't touch? Which, when, and why? Infect Control Hosp Epidemiol 1993; 14:273-275.

12. Lilliy HA, Lowbury EJ, Wilkins MD. Limits to progressive reduction of resident skin bacteria by disinfection. J Clin Pathol 1979;32:382-285.

13. Davies GE, Francis J, Martin RR. 1:6-di-4'chlorophenyldiguanidohexane ('Hibitane'): laboratory investigation of a new antibacterial agent of high potency. $\mathrm{Br} J$ Pharmacol 1954;9:192-193.

14. Harrington C, Walker H. The germicidal action of alcohol. Boston Medical and Surgical Journal 1903;148:548-551.

15. Widmer AF, Perschmann M, Gasser TC, Frei R. Alcohol versus chlorhexidine gluconate for preoperative hand scrub: a randomized cross-over clinical trial. In: Abstracts of the 34th Interscience Conference on Antimicrobial Agents and Chemotherapy; 1994; Orlando, FL. Abstract J180.

\title{
Risk Factors for Nursing Home Outbreaks
}

\section{Gina Pugliese, RN, MS Martin S. Favero, $\mathrm{PhD}$}

Nosocomial infections are an important cause of preventable morbidity and mortality among residents of nursing homes. Outbreaks of infectious disease in nursing homes also have been reported frequently, and most of these outbreaks involve respiratory or gastrointestinal infections. Prevention of outbreaks of communicable diseases in nursing homes is especially important, because infections, and especially respiratory or gastrointestinal infections, may spread rapidly in these settings and involve many residents.

Researchers from the State University of New York at Albany and the New York State Department of Health recently reported the result of a case-cohort study of nursing homes in New York State in 1993 that looked at the institutional risk factors that were found to be associated with the occurrence of nosocomial respiratory and gastrointestinal disease outbreaks. Facility size, staffing patterns, and employee sick-leave policies were found to be the principal risk factors in an unconditional logistic regression model. The risk of having respiratory or gastrointestinal disease outbreaks was greater in larger nursing homes for each 100-bed increase in size, for nursing homes with a single nursing unit, or for those with multiple nursing units with shared staff. The risk was less for nursing homes with paid employee sick-leave policies. Other potential risk factors that were not significantly associated with the risk of disease outbreaks included the ratio of beds per unit, type of sponsorship, daily review of laboratory test results, and the proportion of private beds and patient-to-staff ratio.

Nursing homes with single units (wards) or with multiple units and shared staff were found to have twice the risk of communicable disease outbreaks as those with multiple units with separate staff on each unit. The authors suggest that this might be due to a greater number of patients and staff coming into contact in the former settings, thus increasing the risk of both introduction and transmission of disease. Shared staff on all shifts, or at night and weekends, also may increase the number of different staff with which the patient comes in contact.

Based on these findings, the authors recommend that increased emphasis be placed on proper infection control measures, especially in large nursing homes. The institution of policies for paid employee sick leave and the development of separate staffing patterns in different nursing units also may be beneficial to prevent communicable disease outbreaks in long-term-care facilities.

FROM: Jiehui L, Birkhead GS, Strogatz DS, Coles FB. Impact of institution size, staffing patterns, and infection control practices on communicable disease outbreaks in New York State nursing homes. Am J Epidemiol 1996;143:1042-1049. 